\title{
TINGKAT PENDIDIKAN ORANG TUA: Antar Motivasi Belajar dan Kebiasaan Bermain Game Online
}

\author{
Fidya Hariani 1)* \\ Wiwin Arbaini 2) \\ Dini Palupi Putri ${ }^{3)}$ \\ 1,2,3, Program Studi Pendidikan Agama Islam \\ Institut Agama Islam Negeri (IAIN) Curup, Bengkulu \\ *E-mail: fidyahariani21@gmail.com
}

\begin{abstract}
This study aimed to find out a depiction of educational patterns of parents whose educational background was elementary education in guiding and motivating their children often playing online games. This study applied a qualitative approach. Data were collected through observations and interviews. After the data had been collected, they were then analyzed using the theory of Miles et al, namely data reduction, data presentation and conclusion drawing. The study concluded as follows: first, parents' level of education had an implication on the lack of parental motivation in Tanjung Alam Village. It happened because there were still many parents who did not really understand an educational process. Second, the habit of playing games by teenagers in Tanjung Alam Village became the implication of the lack of parents' knowledge as regards technological development and the negative impact of playing online games so that parents did not realize that this habit had an impact on the lack of learning activities at home.
\end{abstract}

Keywords: Parental education, learning motivation, online games

\begin{abstract}
Abstrak
Penelitian ini bertujuan untuk mengentahui gambaran tentang pola pendidikan orang tua yang berlatar belakang tingkat pendidikan dasar dalam membimbing dan memotivasi anak mereka yang sering bermain game online melalui pendekatan kualitatif. Data dikumpulkan melalui hasil observasi dan wawancara. Setelah data terkumpul lalu dianalisis dengan menggunakan teori Miles dkk yakni reduksi data, penyajian data dan penarikan kesimpulan. Penelitian ini memperoleh simpulan sebagai berikut, pertama, tingkat pendidikan orang tua berimpikasi pada kurangnya motivasi orang tua di Desa Tanjung Alam, hal itu terjadi karena masih banyak orang tua yang belum begitu memahami sebuah proses pendidikan. Kedua, kebiasaan bermain game online remaja di Desa Tanjung Alam merupakan implikasi dari kurangnya pengatahuan orang tua dengan perkembangan teknologi dan dampak negatif bermain game online bagi perilaku remaja sehingga mereka kurang memperdulikan kebiasaan remaja ketika bermain game online yang sering menagabaikan aktivitas pembelajaran di rumah.
\end{abstract}

Kata Kunci: Pendidikan orang tua, Motivasi belajar, game online

\section{PENDAHULUAN}

Orang Tua adalah ayah dan ibu yang diberi amanah oleh Allah SWT, untuk memimpin dan membimbing pertumbuhan dan perkembangan anak-anaknya sehingga memiliki akhlak yang baik atau terhindar dari dekadensi moral (Warsah, 2020). Orang tua merupakan pendidik utama dan pertama bagi anak-anak mereka karena dari merekalah anak-anak mula-mula mendapat pendidikan (Daheri \& Warsah, 
2019). Dengan demikian tingkat pendidikan orang tua akan menentukan cara orang tua membimbing dan mengarahkan anaknya dalam hal pendidikan. Tingkat pendidikan yaitu jenjang pendidikan yang telah ditempuh, sikap yang terbentuk pada masing-masing individu pada setiap jenjang pendidikan formal akan berbeda-beda antara pendidikan Sekolah Dasar (SD), Sekolah Menengah Pertama (SMP), Sekolah Menengah Atas (SMA), dan lulusanb sekolah tinggi (S1), hal inilah yang menjadi latar belakang tingkat pendidikan orang tua dalam membimbing dan mengarahkan anaknya dalam hal pendidikan yang akan ditempuh (Dasmo et al., 2015; Maryam, 2018).

Tingkat pendidikan orang tua yang rendah cenderung sempit wawasannya terhadap pendidikan maupun teknologi, lulusan sekolah menengah sudah dianggap cukup. Sedangkan tingkat pendidikan orang tua yang tinggi akan lebih luas wawasannya terhadap pendidikan maupun teknologi, mereka akan mengarahkan dan membimbing anaknya untuk terus menambah ilmu sehingga anak tersebut mempunyai minat untuk melanjut studi yaitu keperguruan tinggi (Nata, 2018).

Pada dasarnya kenyataan-kenyataan yang dikemukakan di atas itu berlaku dalam kehiduapan keluarga atau rumah tangga dengan bagaimanapun keadaannya. Hal itu menunjukan rasa tanggung jawab orang tua atas kehidupan anak-anak mereka untuk masa kini dan mendatang. Bahkan para orang tua umumnya merasa bertanggung jawab atas segalanya dari kelansungan hidup anak-anaknya. Karenanya tidaklah diragukan bahwa tanggung jawab pendidikan secara mendasar terpikul pada orang tua (Daheri \& Warsah, 2019). Apakah pendidikan itu diakuinya secara sadar atau tidak, diterima sepenuh hatinya atau tidak hal itu merupakan "Fitrah" yang telah dikodratkan Allah SWT kepada setiap orang tua (Warsah, 2018a). Mereka tidak bisa mengelakkan tanggung jawab itu karena merupakan amanah Allah SWT yang dibebankan kepada mereka.

Dengan demikian di pundak orang tua terpikul untuk membimbing pertumbuhan dan perkembangan serang remaja. Namun realitas di Desa Tanjung Alam yang berada di Kecamatan Ujan Mas, Kabupaten Kepahiang yang memiliki luas wilayah $400 \mathrm{Ha}$, yang memiliki jumlah penduduk 284 KK (Kepala Keluarga) dan 965 jiwa (471 laki-laki dan 494 perempuan) yang penduduknya memiliki riwayat pendidikan 372 jiwa tidak sekolah, 40 jiwa pra sekolah, yang tamatan SD 257 jiwa, tamatan SMP 237 jiwa, Tamatan SMA 49 jiwa dan sarjanah berjumlah 7 jiwa, "secara umum banyak remaja yang bermain Game Online, remaja yang bermain Game Online di Desa Tanjung Alam 
diantaranya disebabkan kurangnya motivasi dan perhatian dari orang tua" (Observasi, 18 Juli 2019).

Game Online adalah permainan yang dilakukan secara online melalui internet Game dengan fasilitas Online via internet yang menawarkan fasilitas lebih dibandingkan dengan Game biasa (Adiningtiyas, 2017; Andriyani, 2019; E. P. Handayani, 2020). Dengan Online via internet maka para pemain dapat berkomunikasi dengan pemain lain dari seluruh dunia melalui media Chating. Game Online, kata yang sering digunakan untuk merepresentasikan sebuah permainan digital yang sedang marak di zaman yang moderen ini. Game Online banyak dijumpai dikehidupan seharihari. Walaupun orang berfikir bahwa Game Online identik dengan komputer, tetapi game tidak hanya berorasi dikomputer tetapi Game Online juga bisa di operasikan lewat handphone. Game Online biasanya digunakan untuk refresing atau menghilangkan rasa jenuh si pemain baik itu dalam kegiatan sehari-hari maupun sekedar mengisi waktu luang.

Dengan maraknya permainan Game Online ini, ada remaja yang sengaja berbohong kepada orang tuanya agar dibelikan sebuah Handphone seperti yang dikatakan seorang remaja yang bernama Rizki Alamsyah: "saya bilang kepada orang tua saya bahwa sekolah sekarang ini harus mempunyai sebuah Handphone" (Rizri Alamsyah, Wawancara, 3 November 2019). Dengan demikian orang tuanya yang hanya memiliki riwayat pendidikan Cuma tamatan Sekolah Dasar (SD), tanpa berpikir panjang lagi lansung membelikan anaknya sebuah handphone, adapula yang berbohong kepada orang tuanya agar mendapatkan uang lebih dengan beralasan untuk ngeprint tugas sekolah, mereka juga rela untuk menghabiskan uang jajannya hanya untuk membeli kuota, kebiasaan seperti ini disebabkan karena remaja yang bermain Game Online di Desa Tanjung Alam ini bernotabene masih duduk di bangku sekolah. Jika mereka mengatakan secara terusterang meminta uang untuk membeli kuota yang digunakan untuk bermain Game Online, tentu orang tuanya enggan untuk memberikannya.

Tidak hanya itu, bermain Game Online dapat berpengaruh terhadap perilaku remaja yang malas untuk belajar karena mereka lebih fokus kepada handphonenya dan asik bermain Game yang sedang dimainkannya (Izza, 2019). Perilaku remaja yang mengalami kecanduan Game Online cendrung kurang bersosialisasi dengan lingkungannya, mereka biasanya bermain secara berkelompok dengan pecinta Game 
Online lainnya tetapi mereka tidak menghiraukan antara satu dengan yang lainnya, sehingga membuat mereka kurang bersosialisasi dengan lingkungan sekitar.

Minat bermain Geme Online pada remaja di Desa Tanjung Alam ini cukup besar hal ini dikarenakan orang tua selalu memberi kebebasan kepada anaknya untuk pergi keluar rumah pada malam hari dan berkumpul di jembatan dan warung salah satu warga, mereka mulai berdatangan biasanya pada pukul 18.45 Wib (sesudah ba'da magrib) hingga pukul 00.00 Wib (jam 12 malam), orang tua dari remaja-remaja tersebut tidak pernah melarang anaknya agar tidak keluar rumah, bahkan ada orang tua yang dengan sengaja memberikan kunci rumah kepada anaknya agar anaknya pulan bisa membuka pintu sendiri tanpa membangunkan orang tuanya yang sedang beristirahat. Karena tingkah laku remaja yang sering pulang malam bahkan ada yang pulang pada waktu subuh tidak sedikit remaja yang mendapatkan nilai yang rendah, nilai yang rendah tersebut dipengaruhi oleh motovasi belajar dari orang tua (Observasi, 2 November 2019).

Motivasi adalah keseluruhan daya penggerak baik dari dalam diri maupun dari luar remaja (dengan menciptakan serangkaian usaha untuk menyediakan kondisikondisi tertentu) yang menjamin kelangsungan dan memberikan arah pada kegiatan belajar, sehingga tujuan yang dikehendaki oleh subjek belajar itu dapat tercapai (Mahlianurrahman, 2017; Warsah, 2018b). Berdasarkan pengertian tersebut dapat dikatakan bahwa motivasi merupakan sebuah motor yang mampu menjadi penggerak dan menggerakkan seseorang untuk melakukan sesuatu atau kegiatan yang mengarah pada tercapainya suatu tujuan yang dikehendaki (Hafid, 2017; R. Handayani, 2019; Jamil, 2019). Dengan demikian motivasi merupakan hal yang penting yang harus dimiliki oleh setiap orang dalam rangka mencapai tujuan yang telah ditetapkan.

Peran orang tua dalam pendidikan merupakan sesuatu yang sangat penting dan menjadi salah satu faktor yang mempengaruhi ketercapaian belajar remaja (Rumbewas et al., 2018; Wahidin, 2020). Peran orang tua juga merupakan salah satu faktor eksternal yang mempengaruhi motivasi belajar remaja, di mana mereka memiliki motivasi belajar yang tinggi atau rendah dipengaruhi oleh peran orang tua(Hasgimianti et al., 2017; Mumu et al., 2019; Pratiwi, 2017).

Setelah peneliti melakukan penelitian tentang cara orang tua untuk memotovasi belajar remaja, beberapa dari dari remaja merasa memiliki motivasi belajar yang rendah, mereka kurang adanya dukungan dan dorongan dari orang tua dalam belajar, 
Rendahnya motivasi belajar juga terkait dengan kondisi keluarga yang berorientasi pada bekerja.

Penelitian Fitria dan Aini berkaitan dengan motivasi belajar remaja juga terkait dengan peran orang tua, di mana peran orang tua tersebut memberikan pengaruh yang besar. Namun dalam penelitian tersebut terungkap bahwa beberapa kasus terjadi banyak orang tua yang masih belum memahami dan menyadari perannya dalam pendidikan anak termasuk dengan motivai belajar. Orang tua yang tidak tahu peran mereka dalam membantu anaknya dalam pendidikan, sehingga terkadang orang tua hanya mengetahui dan bertanggungjawab sekedar menyekolahkan anaknya tetapi mengabaikan pendidikan dari orang tua itu sendiri, termasuk dorongan dan motivasi belajar bagi anak tersebut (Fitria \& Aini, 2019). Padahal seperti yang diketahui bahwa pendidikan yang pertama kali dikenal oleh anak adalah dari keluarga dan orang tua berperan penting didalamnya.

Efek dari kurangnya perhatian dari orang tua, tidak sedikit remaja yang terjebak dan kecanduan game online, salah satunya tantangan (Asman, 2020). Dalam setiap game ada tantangan yang membuat pecandunya terus merasa tertantang, sehingga pada akhirnya orang kecanduan game online akan merasa ketergantungan terus menerus dan tidak bisa lepas dari game(Akbar \& Ahmad, 2018; Halawa, 2018). Game online akan mengurangi aktivitas positif yang seharusnya dijalani oleh remaja pada usia perkembangan mereka remaja yang mengalami ketergantungan pada aktivitas games akan mempengaruhi motivasi belajar sehingga mengurangi waktu belajar dan waktu untuk bersosialisasi dengan teman sebaya mereka (Jafri et al., 2018). Jika ini berlangsung terus menerus dalam waktu lama, diperkirakan remaja akan menarik pada pergaulan sosial, tidak peka dengan lingkungan, bahkan bisa membentuk kepribadian sosial, dimana remaja tidak mempunyai kemampuan beradaptasi dengan lingkungan sosialnya.

Berdasarkan data di atas dapat diketahui bahwa minat remaja Desa tanjung Alam terhadap Game Online cukup besar karena mereka bermain Game kurang lebih ( \pm ) 6 jam, hal seperti ini dapat terjadi karena kurangnya perhatian dari orang tua, kesimpulan sementara peneliti pada observasi awal terdapat $66 \%$ atau 40 orang, orang tua terlalu memberikan kebebasan kepada anaknya untuk bersosialisasi melalui dunia maya atau internet, kurangnya pengawasan dan kepekaan dari orang tua 
menjadi salah satu faktor penyebab prilaku remaja yang kecanduan Game Online ini tidak terbendung.

Remaja tersebut mengatakan lebih suka bermain game online daripada berkumpul dengan teman-temannya dengan alasan bermain game online lebih menyenangkan, dapat menghilangkan rasa bosan dan dapat melampiaskan kekesalan mereka di kehidupan nyata. Ada remaja mengatakan merasakan ada sesuatu yang hilang atau bosan jika tidak bermain game online dalam sehari dan akan timbul perasaan senang saat memulai bermain game online kembali. Semua remaja menghabiskan waktu bermain game online lebih dari 6 jam/hari dan biasanya meningkat setiap harinya (Observasi 18 Februari 2020).

Penelitian yang dilakukan oleh rayadi dan kawan-kawan, tentang kebiasaan remaja bermain Game Onlie, yaitu disebabkan kurangnya pengawasan dari orang tua, dengan demikian Bertolak dari fenomena tersebut maka penulis tertarik untuk melakukan pengembangan tentang hal yang bersifat kecanduan Game Online yang terjadi pada remaja di Desa Tanjung Alam, dan tingkat pendidikan orang tua yang berbeda-beda dan perhatian orang tua terhadap sikap bersosialisasi remaja, sehingga penulis melakukan penelitian tentang "Tingkat Pendidikan Orang Tua: Antar Motivasi Belajar Kebiasaan Remaja Bermain Game Online di Desa Tanjung Alam”.

\section{METODE}

Penelitian ini menggunakan analisis data yang bersifat kualitatif yang tidak bisa diukur dengan angka data, melaikan dikumpulkan melalui wawancara, observasi, dan dokumentasi (Gironés Guillem et al., 2018; Setiawan, 2018). Tujuan penelitian ini ialah untuk menemukan gambaran tentang tingkat pendidikan orang tua antar motivasi belajar dan kebiasaan remaja bermain Game Online di Desa Tanjung Alam dan untuk mengetahui apakah tingkat pendidikan Orang Tua dapat mempegaruhi motivasi belajar remaja yang mempunyai kebiasaan bermain Game Online.

Subjek dalam penelitian adalah kepala desa, orang tua dan remaja yang ada di Desa Tanjung Alam. Selain itu data didapat dari hasil observasi dalam kehidupan sehari-hari remaja di Desa Tanjung Alam. Kemudian data didapat dari Kepala Desa yang berupa, sejarah desa, struktur desa, jumlah penduduk, dan tingkat pendidikan penduduk Desa Tanjung Alam(Roulston, 2014). Setelah data terkumpul dilakukan analisis data sehingga diperoleh kesimpulan sebagai jawaban permasalahan tentang 
tingkat pendidikan orang tua kaitannya dengan motivasi belajar dan kebiasaan remaja bermain game online (Miles et al., 2014).

\section{HASIL DAN PEMBAHASAN}

\section{Antara Tingkat Pendidikan Orang Tua dan Motivasi Belajar Remaja}

Berdasarkan data hasil wawancara di Desa Tanjung Alam, motivasi belajar yang diberikan kepada remaja, seperti yang dikatakan oleh ibu Lihauna sebagai berikut "saya hanya tamatan Sekolah Dasar (SD), saya selalu menyarankan agar anak saya belajar setiap malam, setiap saya tanya apakah dia sudah belajar atau belum, dia selalu menjawab bahwa dia sudah belajar , dengan ia menjawab seperti itu ya saya percaya saja dan anak saya selalu pergi setiap malam keluar rumah tanpa saya ketahui dia akan pergi kemana dan akan melakukan apa.

Hal tersebut serupa dikatakan oleh Juliana yaitu selaku orang tua remaja di Desa Tanjung Alam adalah sebagai berikut "anak saya juga melakukan hal yang sama dengan anak ibu Lihauna lakukan, yaitu dia selalu mengatakan bahwa dia sudah belajar dan saya selalu mempercainya, saya juga tidak pernah mengawasi anak saya belajar karena saya rasa merek sudah besar dan sudah mengerti anak tanggung jawabnya sebagai seorang pelajar"(Wawancara, 4 Februari 2020).

Namun hal yang berbeda yang disampaikan oleh bapak Harisman Suhadi selaku orang tua remaja, beliau mengatakan bahwa: "saya dan istri saya selalu memberikan bimbingan dan mengatakan hal-hal yang membuat anak saya mau untuk belajar dan saya dengan istri selalu mengawasi anak saya pada saat ia belajar, jika disaat ia lagi belajar dan saya masih banyak kerjaan, maka saya akan meminta atau saya akan melihat apa yang dikerjakan anak saya" (Wawancara, 4 Februari 2020).

Hal serupa juga dikatakan oleh ibu Mariana selaku orang tua remaja, ia mengatakan bawa: "saya selalu mengatakan kepada anak saya belajarlah dengan baik supaya nanti kamu bisa menjadi orang tidak seperti ibu, dengan mendengar hal tersebut alhamdulillahnya anak saya rajin belajar dan saya selalu mengawasi anak saya" (Wawancara, 4 Februari 2020).

Menurut ibu Merai Yuna selaku orang tua remaja ia mengatakan bahwa: "kalau saya ya terserah anak saya mau belajar ya silahkan, tidak mau belajar juga tidak apa, saya tidak mau terlalu pusing memikirkannya, karena saya sudah capek 
setiap hari harus ke kebun dan bila dirumah saya cuma mau istirahat" (Wawancara, 24 Februari 2020). Setelah peneliti melakukan wawancara dengan bapak Lailatul Qodri ia mengatakan sebagai berikut :"saya orang tua memiliki tanggung jawab terhadap anak saya, yaitu mengasuh dan membimbing anak saya dengan baik, saya mengajari anak saya dengan kasih sayang, saya selalu mengatakan hal-hal positif kepada anak saya sehingga pada saat ia mendengar apa yang saya katakan ia melakukannya" (Wawancara, 24 Februari 2020)

Berdasarkan hasil wawancara dengan ibu Misnawati selaku orang tua dari remaja di Desa Tanjung Alam, beliau mengatakan: "Saya selalu memperhatikan anak saya belajar, mulai dari mengingatkannya belajar apabila dia belum belajar, dan menemani ketika belajar. Sehingga saat anak saya mengalami kesulitan saat belajar, saya bisa membantu. Saya kadang memberikan nasehat kepada anak saya bahwa kalau dia rajin belajar, dia dapat mendapat ranking di kelas. Anak sayapun menjadi semangat belajar. pada semester kemarin alhamdulillah dia mendapat ranking dan masuk 5 besar" (Wawancara, 26 februari 2020).

Dan menurut bapak herman koko selaku orang tua dari remaja di Desa Tanjung alam, beliau mengatakan: "saya selalu menemani anak saya belajar sampai selesai, akan tetapi kadang- kadang masih suka malas belajar dan Saya memberikan pengertian kalau dia sebaiknya jangan terlalu banyak bermain agar dapat belajar dengan semangat. Kalau belajarnya semangat kan nanti jadi paham dan masuk ilmunya, sehingga saat ujian nanti mendapat nilai yang baik" (Wawancara, 26 Februari 2020). Sementara itu menurut ibu Suheruna selaku orang tua remaja di Desa Tanjung Alam yaitu sebagai berikut "saya tidak pernah mengawasi anak saya belajar, walapun begitu saya selalu mengingatkan bahwa anak saya harus belajar saya mengatakan bila ia rajin belajar nanti bisa mendapat nilai yang baik" (Wawancara, 26 Februari 2020).

Menurut bapak Supardi selaku orang tua remaja di Desa Tanjung Alam yaitu sebagai berikut "anak saya biasanya belajar waktu habis magrib dan tanpa harus disuruh belajar, dia akan belajar. Saya selalu mendampingi dia belajar di kamarnya. Berhubung anak saya itu selalu mengatakan bahwa ia ingin menjadi orang sukses, maka saya mengatakan jika ia mau menjadi orang sukses maka ia harus rajin belajar" (Wawancara, 26 Februari 2020). Menurut bapak muhammad munzir selaku orang tua remaja di Desa Tanjung Alam ialah sebagai berikut. "saya 
tidak pernah mengawasi anak saya beajar, saya hanya bertantya saja apakah ia sudah belajar atau belum. Saya selalu mengatakan kepada anak saya jika ingin menjadi orang sukses ya harus rajin belajar" (Wawancara. 26 Februari 2020).

Pendapat yang sama disampaikan oleh bapak Muhtaridi selaku orang tua remaja di Desa Tanjung Alam yaitu sebagai berikut. "saya tidak pernah melihat ataupun menemani anak saya ketika belajar. Namun saya hanya mengatakan kepada anak sayabila ia mengiginkan nilai yang baik maka dia harus rajin belajar, dengan belajar maka soal-soal yang ia hadapi akan lebih mudah" (Wawancara, 01 Maret 2020).

Menurut ibu Inarianti selaku orang tua remaja di Desa Tanjung Alam ia mengatakan bahwa "anak saya ya belajar mandiri, anak saya belajarnya dikamar dan saya menonton TV di ruang TV. Saya selalu menyarankan anak saya bahwa awal dari kesuksesan adalah belajar"((Wawancara, 01 Maret 2020).

Dapat disimpulkan, berdasarkan wawancara dengan orang tua di Desa Tanjung Alam menyatakan bahwa orang tua senantiasa memberikan motivasi kepada anak-anaknya agar mereka selalu giat belajar. Motivasi yang diberikan orang tua tersebut tentu saja berbeda-beda antara satu sama lain. Dengan demikian, orang tua menyadari akan pentingnya pemberian motivasi atau dukungan semangat kepada anak sehingga mereka terdorong untuk semakin giat belajar.

Orang tua mengatakan bahwa dengan memberikan motivasi belajar dalam berbagai bentuk kepada anak ternyata dapat meningkatkan gairah belajar mereka. Adapun gairah belajar anak ditunjukan melalui sikapnya yang gemar mengulang pelajaran disekolah yang disertai dengan dampingan dari orang tua. Anak juga merasa senang mengerjakan pekerjaan sekolah jika ditemani atau dibantu oleh orang tuanya.

Hasil wawancara juga menunjukan bahwa ada beberapa kendala yang dihadapi orang tua dalam memotivasi belajar anak. Kendala tersebut kadang kala sering menjadi hambatan bagi beberapa orang tua dalam mendampingi anaknya belajar. Akan tetapi, orag tua terus berupaya mengatasi kendala tersebut sehingga pemberian motivasi belajar kepada anak dapat terus diberikan.

Dengan melakukan wawancara dengan beberapa remaja, maka peneliti mendapatkan jawaban yang di sampaikan oleh Sefti Ayu Rolita adalah sebagai 
berikut: "saya selalu menuruti kata orang tua saya bahwa saya harus belajar dengan baik supaya nanti saya bisa menjadi orang yang berguna dan menjadi orang yang dibanggakan oleh orang tua saya, walaupun terkadang say jenuh mendengar perkataan orang tua saya, tetapi saya jalani aja toh beliau juga memberikan waktu beljaar saya cuman 30 menit, selesai itu say bebas mau ngapain aja" (Wawancara, 24 Februari 2020).

Lain halnya dengan yang di sampaikan oleh Solihin Hardiyansah, ia mengatakan bahwa : "ia orang tua saya mengatakan saya sudah belajar atau belum saya selalu mengatakan bahwa saya sudah belajar, toh orang tua saya tidak tau saya sudah belajar atau belum, karena orang tua saya selalu menonton TV tanpa melihat dan menanyakan apa yang saya pelajari" (Wawancara, 24 Februari 2020). Menurut Juan Toni, ia mengatakan bahwa "orang tua saya tidak pernah mengawasi saya di waktu belajar. Waktu belajar pergunakan untuk bermain Game Online, karena menurut saya bermain game itu lebih menyenangkan dari pada saya harus melihat buku-buku dan mengerjakan tugas yang monoton" (Wawancara, 24 Februari 2020).

Menurut Wafit Aziza ia mengatakan bahwa "orang tua saya selalu mengawasi saat saya belajar. Terkadang saat saya tidak bisa menjawab ataupun mengerjakan tugas, orang tua saya selalu mengajari saya dan selalu memberikan kata kata yang membuat saya semnagta untuk belajar" (Wawancara, 24 Februari 2020). Lain halnya dengan yang dikemukakan oleh Marvel Pahreza ia mengatakan bahwa "orang tua saya tidak penah mengawasi saya belajar, karena orang tua saya terlalu asik dengan sinetron favoritnya. Orang tua saya juga tidak menghiraukan dengan apa yang saya kerjakan saya mau ngapain aja ya silahkan" (Wawancara, 26 Februari 2020).

Setelah peneliti melakukan wawancara dengan remaja secara lansung ternyata motivasi yang diberikan orang tua remaja itu masih kurang, karena orang tua lebih banyak mementingkan yang lain dibandingkan mengawasi dan mendampingi anaknya secara lansung, karena hal tersebut membuat remaja menjadi melupakan pelajarannya dan meninggalkan pembelajarannya hanya untuk melakukan sesuatu, adapula remaja yang sengaja berbohong dengan mengatakan bahwa dia telah belajar padahal waktu nya dipergunakan untuk halhal yang lain salah satunya yaitu bermain handphone dan bermain Game Online. 
Dalam penelitian ini peneliti mendapati ternyata pendidikan orang tua tidak mengpengaruhi motivasi belajar anak, karena banyak orang tua yang memiliki pendidikian rendah tetapi tetap mengawasi dan memotivasi anaknya supaya belajar dengan baik.

\section{Antara Tingkat Pendidikan Orang Tua dan Kebiasaan Remaja Bermain Game} Online

Setelah peneliti melihat bahwa remaja di Desa Tanjung alam meski banyak yang ketergantungan dengan game online dan jarang bergaul dengan lingkungan sekitar tetapi terkadang mereka masih berkumpul dengan teman-teman sebayanya walaupun dalam perkulpulan tersebut mereka selalu memegang hadphone dan bermain Game Online sapai tak ingat waktu.

Setelah peneliti melakukan obserpasi kepada remaja untuk mengetahui seberapa besarnya kegemaran mereka terhadap Game Online. Seperti yang dikatakan oleh Agung Wirayuda selaku remaja di Desa tanjung alam yaitu sebagai berikut: "saya jarang bermain Game Online, Saya tidak pernah merasa bahwa Game Online itu hanya menghabiskan waktu saya, Tidak pernah juga terpikir oleh saya bahwa Game Online bisa menambah wawasan saya tentang teknologi, Saya sering menggunakan uang saku saya hanya untuk membeli kuota karena orang tua saya tidak memberikan uang untuk membeli kuota.

Kadang-kadang saya meninggalkan tugas sekolah hanya untuk bermain Game Online, tetapi saya tidak pernah berbohong dengan orang tua saya dan saya juga tidak pernah bolos sekolah hanya untuk bermain Game Online, seringkali saya itu bermain Game Online setelah saya menyelesaikan tugas sekolah karena hal tersebut saya jarang lupa akan waktu ketika saya lagi bermain Game Online karena orang tua saya sering melarang saya untuk bermain Game Online, karena hal tersebut alhamdulillahnya prestasi saya disekolah tidak pernah mengalami penurunan. Saya bermain Game Online itu kadang-akang karena diajakin oleh teman saya namun terkadang juga saya merasa sepi jika tidak bermain Game Online akan tetapi saya baru akan bermain Game ketika saya sudah pulang sekolah dan terkadang juga saya merasa tenang jika sudah bermain Game Online" (Wawancara. Agung Wirayuda 25 Mei 2020).

Menurut Riski Alam Syah selaku remaja di Desa Tanjung Alam ia mengatakan bahwa: "saya sangat menyukai Game Online, tetapi terkadang saya merasa game 
online itu hanya menghabiskan waktu dan terkadang juga saya berfikir bahwa bermain Game Online bisa menambah wawasan tentang ilmu teknologi, saya rela bermain menghabiskan waktu saya berjam-jam hanya untuk bermain Game Online,saya selalu menggunakan uang saku hanya untuk membeli kuota dan terkadang juga saya rela meninggalkan tugas sekolah demi bermain Game Online saya juga selalu merasa bahwa permainan Game Online sangat menyenangkan, saya tidak pernah berbohong kepada orang tua saya karena orang tua saya tidak pernah melarang saya bermain Game Online, terkadang saya rela bolos sekolah demi untuk bermain Game Online dan saya sangat jarang sekali bermain Game Online setelah menyelesaikan tugas sekolah, setiap hari saya selalu bermain Game Online dan saya sangat sering lupa waktu ketika lagi bermain Game Online, prestasi saya di sekolah juga kadang-kadang murun, saya bermain Game Online kadangkadang karena diajak oleh teman tetapi tak jarang pula saya merasa sepi jika saya tidak bermain Game Online karena setiap saya sudah bermain Game Online saya merasa tenang" (Wawancara, 25 Mei 2020).

Sedangkan menurut Arianda Saputra selaku relaja di Desa Tanjung Alam ia mengatakan bahwa: "terkadang saya suka bermain Game Online terkadang juga saya merasa bahwa Game Online itu hanya menhabiskan waktu tetapi tak jarang pula saya berpikir bahwa bermain Game Online itu bisa menambah wawasan tentang ilmu teknologi, saya tidka pernah menggunakan uang jajan saya untuk membeli kuota terkadang saya rela meninggalkan tugas sekolah hanya untuk bermain Game Online sehingga hal tersebut membuat prestasi belajar saya menjadi menurun, orang tua saya tidak pernah melarang saya untuk bermain game online sehingga membuat saya merasa sepi bila tidak bermain dan saya juga selalu merasa tenang bisa sudah bermain Game Online" (Wawancara, 25 Mei 2020).

Menurut Maechael Leo selaku remaja di Desa Tanjung Alam ia mengatakan bahwa: "saya suka bermain Game Online kadang-kadang saya merasa Game Online hanya menhhabiskan waktu tetapi tak jarang pula saya berpikir bahwa bermain Game Online itu bisa menambah wawasan tentang teknologi, saya rela berjam-jam bermain handphone hanya untuk bermain Game Online saya rela menghabiskan uang saku saya hanya untuk membeli kuota, terkadang saya rela meninggalkan tugas sekolah hanya untuk bermain Game Online karena saya merasa mermain Game Online itu sangat menyenangkan, hal tersebut terkadang membuat prestasi 
saya menurun karena orang tua tidak pernah melarang saya bermain Game Online. Terkadang saya sering lupa waktu ketika saya lagi bermain Game Online terkadang saya bermain Game Online karena diajak teman tak jarang pula saya merasa sepi jika tidak bermain Game Online dan saya akan merasa tenang jika saya telah bermain Game Online" (Wawancara, 25 Mei 2020).

Adapun menurut Davi Josa Ramadani Selaku Remaja di Desa Tanjung Alam ia mengatakan bahwa: "saya suka bermain game onlinesaya selalu merasa bahawa Game Online hanya menghabiskan waktu tetapi saya juga selalu berpikir bahwa bermain Game Online itu bis amenambah wawasan saya, saya juga rela menghabiskan waktu saya hanya untuk bermain, saya sangat sering menggunakan uang saku saya untuk memberi kuota, saya rela meninggalkan tugas sekolah karena hal tersebut membuat prestasi saya menurun, orang tua asaya juga tidak pernah melarang saya untuk bermain Game Online, saya juga merasa bahwa permainan Game Online itu sangat menyenagkan sehingga membuat saya setiap hari bermain Game Online karena Game Online juga pernah membuat saya lupa waktu, saya juga merasa terganggu apabilah belum menyelesaikan permaianan saya merasa sepi jika tidak bermain game terkadang saya bermain game itu karena diajak oleh teman saya" (Wawancara, 25 Mei 2020).

Menurut Fadiah Mutiah selaku remaja di Desa Tanjung Alam ia mengatakan bahwa: "saya tidak terlalu suka dengan Game Online saya merasa Game Online itu hanya menhabiskan waktu, saya juga sering berpikir bahwa bermain Game Online itu bisa menambah wawasan tentang ilmu teknologi, tidak pernas saya menghabiskan waktu hanya untuk bermain Game Online saya juga jarang membi kuota menggunakan uang saku saya tidak pernah meninggalkan tugas sekolah dan saya juga tidak pernah bolos sekolah perstasi saya juga jarang sekali mengalami penurunan, orang tua saya selalu melarang saya bermain Game Online akan tetapi saya juga ada bermain Game Online walapuan tidak setiap hari karena saya tidak terlalu mengerti tentang Game Online, biasanya saya bermain Game Online itu karena diajak oleh teman saya bermain game setelah saya pulang dari sekolah" (Wawancara, 26 Mei 2020).

Namun hal berbeda dengan yang dikatakan oleh M. Irsyat Al Fikri selaku remaja di Desa Tanjung Alam ia mengatakan bahwa: "saya sangat menyukai permainan Game Online walapun saya merasa Game Online itu hanya 
menghhabiskan waktu saya juga tidak pernah berpikir jika Game Online itu bisa menambah wawasan tentang ilmu teknoligi, saya rela berjam-jam bermain handphone hanya untuk bermain Game Online walaupuan begutu saya tidak pernah menggunakan uang saku saya untuk membeli kuota,saya itu sering lupa waktu bila sudah bermain Game Online walau terkadang saya tidak terlalu mengerti saya bermain Game Online itu karena diajak olehteman dan saya merasa tenang jika sudah bermain Game Online. Saya tidak perah meninggalkan tugas sekolah demi bermain Game Online saya tidak pernah bolos sekolah akan tetapi prestasi saya selalu menurun tetapi tetap saja orang tua saya tidak pernah melarang saya untuk bermain Game Online" (Wawancara, 26 Mei 2020).

Menurut Fiksi Erlanda selaku remaja di Desa Tanjung Alam ia mengatakan bahwa: "saya suka bermain Game Online terkadang saya merasa Game Online itu hanya menghabiskan waktu saya juga tidak pernah berpikir bahwa bermain Game Online itu bisa menambah wawasan tentang ilmu teknologi, saya sering berjamjam bermain handphone hanya untuk bermaon Game Online, saya juga sering menghabiskan uang saku hanya untuk membeli kuota, tetapi saya tidak pernah meninggalkan tugas sekolah saya juga tidak pernah bolos sekolah, prestasi sekolah saya pun tidak pernah turun, walapuan orang tua saya jarang melarang saya agar tidak bermain Game Online.

Saya juga merasa nahwa permainan Game Online itu sangat menyenangkan saya tetap mendahulukan tugas sekolah saya, saya memang bermain Game Online setiap hari tetapi hal itu tidak pernah membuat saya lupa waktu walapun saya selalu merasa terganggu apabila belum menyelesaikan permaianan saya, saya juga kerap merasa sepi bila tidak bermain dan saya akan merasa tenang jika sudah bermain Game Online" (Wawancara, 26 Mei 2020).

Menurut Pajri Alparezi selaku remaja di Desa Tanjung Alam ia mengatakan bahwa: "saya suka bermain Game Online kadang-kadang saya merasa Game Online itu hanya menghabiskan waktu tetapi saya sering berpikir bahwa bermain Game Online biosa menmbah wawasan tentang ilmu teknologi, saya pun rela berjam-jam bermain handphone hanya untuk bermain Game Online kadang-kadang saya juga menggunakan uang saku untuk membeli kuota, walapun demikian, saya jarang sekali meninggalkan tugas sekolah saya tidak pernah bolos sekolah dan saya akan bermain Game Online ketika waktu pulag sekolah, akan tetapi prestasi belajar saya 
kadang-kadang menurun, walapun begitu orang tua saya tidak pernah melarang saya bermain Game Online, sayapun sering sekali lupa waktu bila saya sudah bermain, setiap hari saya bermain walaupun kadang-kadang saya tidak terlalu mengerti tenang Game Online tetapi saya akan merasa terganggu apabila saya belum menyelesaikan permainan, saya bermain Game Online itu selalu diajak teman walaupun begitu saya merasa sepi bila tidak bermain Game Online dan saya akan merasa tenang jika saya sudah bermain" (Wawancara, 26 Mei 2020).

Menurut Andre Tanjung selaku remaja di Desa Tanjung Alam ia mengatakan bahwa: "saya tidak terlalu suka bermain Game Online, karena saya merasa itu hanya meghabiskan waktu saya juga tidak pernah berpikir jika itu bisa menambah wawasan tentang ilmu teknologi. Saya sangat jarang menghabiskan wkatu saya untuk bermain game walaupun begitu saya sering menggunakna uang saku untuk membeli kuota terkadang juga saya rela meninggalkan tugas sekolah saya hanya untuk bermain Game Online karena saya merasa Game Online itu menyenangkan tetapi saya tidak pernah bolos sekolah, saya bermain game di waktu saya pulang sekolah dan prestasi saya juga tidak pernah turun, itu karena orang tua saya selalu melarang saya untuk bermain game, tapi bila saya tidak bermain game saya merasa sepi" (Wawancara, 26 Mei 2020).

Menurut Parer Tri Angga Saputra selaku remaja di Desa Tanjung Alam ia mengatakan bahwa: "saya suka bermain game online walapun kadang-kadang saya merasa Game Online hanya menghabiskan waktu tetapi saya juga berfikir bahwa bermain Game Online itu bisa menambah wawasan tentang ilmu teknologi. Saya sangat jarang menghabiskan waktu berjam-jam hanya untuk bermain Game Online walaupun begitu saya selalu menggunakan uang saku untuk membeli kuota kadangkadang saya rela meninggalkan tugas sekolah dan sering merasa Game Online itu sangat menyenangkan bahkan kadang-kadang saya rela bolos sekolah saya jarang sekali menyelesaikan tugas sekolah terlebih dahulu karena setiap hari saya bermain game saya sering lupa waktu orang tua saya pun tidak pernah melarang dan prestasi saya disekolah suka anjlok. Walapun begitu saya tetap merasa terganggu apabila belum menyelesaiakn permainan saya, walapun tenman saya jarang mengajak saya untuk bermain, saya akan tetap bermain karena biloa sudah bermain saya akan merasa lega seperti ada beban yang terlepaskan" (Wawancara, 26 Mei 2020). 
Menurut Ricat Alfarizi selaku remaja di Desa Tanjung Alam ia mengatakan bahwa: " saya sangat menyukai permainan Game Online, terkadang saya meras agame online hanya menghabiskan waktu tetapi menurut saya dengan bermain Game Online itu bisa menambah wawasan tentang imlu teknologi, saya pun tak keberatan bila harus memegang handphone seharian hanya untuk bermain Game Online, saya juga selalu menggunakan uang saku unjtuk membeli kuota, bahkan saya sangat rela meninggalkan tugas sekolah saya demo game karena saya merasa game itu sangat menyenangkan, kadang-kadang saya juga berbohong kepada orang tua tetapi saya tidak pernah bolos sekolah tetapi saya lebih mengutamakan game ketimbang tugas sekolah, setiap hari saya bermain sampai lupa waktu, melihat kelakuan saya, orang tua saya kadang-kadang juga melarang saya tetapi saya sering merasa terganggu bila belum menyelesaikan permainan, walapun semua itu berpengaruh terhadap prestasi belajar saya yang terus menurun" (Wawancara, 26 Mei 2020).

Menurut Meigi selaku remaja di Desa Tanjung Alam ia mengatakan bahwa: "saya tidak terlalu suka bermain Game Online, saya jarang merasa bahwa game online itu menghabiskan waktu walapun kadang-kadang saya berpikri bahwa Game Online bisa menambah pengetahuan kadang-kadang saya rela berjam-jam menghabiskan waktu hanya untuk bermain game, saya jarang menggunakan uang saku untuk membeli kuota dan saya tidak pernah rela meninggalkan tugas sekolah dan saya bermani game setelah saya menyelesaikan tugas, saya juga tidak pernah bolos sekolah walaupun saya merasa permainan game itu sangat menyenagkan, kadang-kadang setiap hari saya bermain game dan lupa waktu karena saya sering merasa terganggu apabila belum menyelesaikan permainan saya walaupun saya bermain game itu karena diajak teman" (Wawancara, 30 mei 2020).

\section{KESIMPULAN DAN SARAN}

\section{Kesimpulan}

Uraian di atas merupakan penjabaran dari hasil penelitian yang dilakukan di Desa Tanjung Alam terkait Tingkat pendidikan orang tua: antar motivasi belajar dan kebiasaan remaja bermain game online. Berdasarkan uraian tersebut dapat ditarik kesimpulan sebagai berikut: Pertama, tingkat Pendidikan Orang Tua Dengan Motivasi Belajar antara lain motivasi yang diberikan orang tua remaja itu masih kurang, karena 
orang tua lebih banyak mementingkan yang lain dibandingkan mengawasi dan mendampingi anaknya secara lansung, karena hal tersebut membuat remaja menjadi melupakan pelajarannya dan meninggalkan pembelajarannya hanya untuk melakukan sesuatu, adapula remaja yang sengaja berbohong dengan mengatakan bahwa dia telah belajar padahal waktu nya dipergunakan untuk hal-hal yang lain salah satunya yaitu bermain handphone dan bermain Game Online.

Kedua, Tingkat Pendidikan Orang Tua Dengan Kebiasaan Remaja Bemain Game Online. pendidikan orang tua berpenagruh terhadap kebiasaan anak yang suka bermain Game Online, karena orang tua dari remaja notabennya lebih banyak hanya tamanan Sekolah Dasar (SD) sehingga membuat orang tua Gagap Teknologi (Gamtek) terhadap perkembangan teknologi sekarang. Karena orang tua gaptek maka banyak dari orang tua membiarkan anaknya bermain game terus menerus tanpa mengetahui dampak negatif yang ada pada handphone terutama remaja yang menggunakan handphone nya untuk digunakan bermain Game Online dan orang tua terlalu memberikan kebebasan kepada anaknya untuk bersosialisasi melalui dunia maya atau internet, kurangnya pengawasan dan kepekaan dari orang tua menjadi salah satu faktor penyebab prilaku remaja yang kecanduan Game Online ini tidak terbendung.

\section{Saran}

Remaja adalah masa peralihan anak-anak menuju dewasa, fase ini adalah fase yang paling senditif dialami oleh mereka. Fase ini sering disebut juga dengan fase pubertas, sehingga anak mulai merasa mampu menentukan sikap tanpa harus diinterpensi oleh orang tua. Ketika anak salah memilih bergaul dengan pergaulan yang kurang baik, maka mereka akan mudah terpengaruh dan itu berimplikasi pada sikap memberontak kepada orang tua bahkan kurangnya giarah belajar. Melalui artikel ini peneliti memberikan saran kepada setiap orang tua untuk mengawasi pergaulan siswa jangan sampai mereka terjerumus kedalam pergaulan bebas tanpa batas dan bahkan perilaku yang melanggar norma agama, adat dan hukum.

\section{DAFTAR PUSTAKA}

Adiningtiyas, S. W. (2017). Peran Guru Dalam Mengatasi Kecanduan Game Online. KOPASTA: Jurnal Program Studi Bimbingan Konseling, 4(1), Article 1. https://doi.org/10.33373/kop.v4i1.1121

Akbar, A., \& Ahmad, M. R. S. (2018). Pengaruh Game Online Terhadap Motivasi Belajar Siswa di Kelas X SMA Negeri 16 Makassar. Jurnal Sosialisasi: Jurnal Hasil 
Pemikiran, Penelitian Dan Pengembangan Keilmuan Sosiologi Pendidikan, 0(0), 8-11. https://doi.org/10.26858/sosialisasi.v0i0.12127

Andriyani, Y. F. Y. P. T. (2019). Pengaruh Kecanduan Game Online Terhadap Perilaku Konsumtif Siswa Pengguna Game Online. Jurnal Riset Terapan Akuntansi, 2(2), 169-180. https://doi.org/10.5281/zenodo.3840736

Asman, A. (2020). Parental Rights and Obligations to Children in the Era of Industrial Revolution 4.0 (Islamic Family Law perspective). SAMARAH: Jurnal Hukum Keluarga Dan Hukum Islam, 4(1), 232-258. https://doi.org/10.22373/sjhk.v4i1.6899

Daheri, M., \& Warsah, I. (2019). Pendidikan akhlak: relasi antara sekolah dengan keluarga. At-Turats: Jurnal Pemikiran Pendidikan Islam, 13(2), 1-20.

Fitria, E. Y., \& Aini, W. (2019). Hubungan Pemahaman Orang Tua terhadap MDTA dengan Motivasi Memasukkan Anaknya ke MDTA. JFACE: Journal of Family, Adult, and Early Childhood Education, 1(3), 361-370. https://doi.org/10.5281/zenodo.3728062

Gironés Guillem, P., Burguete, D., Machado, R., Domínguez Santamaría, J. M., \& LilloCrespo, M. (2018). Qualitative Research Process Applied to Organ Donation.

Hafid, M. (2017). Pengaruh Motivasi dan Kompetensi Guru Terhadap Kinerja Guru Sekolah dan Madrasah di Lingkungan Pondok Pesantren Salafiyah Syafi'iyah Sukorejo. Jurnal Pendidikan Islam Indonesia, 1(2), 293-314.

Halawa, A. (2018). Hubungan Bermain Game Online Dengan Prestasi Belajar Siswa Kelas 4 Di MI Darussalam Jambangan Surabaya. Jurnal Keperawatan, 7(1), Article http://jurnal.stikeswilliambooth.ac.id/index.php/Kep/article/view/113

Handayani, E. P. (2020). Efektivitas Teknik Pengkondisian Aversi Dalam Mereduksi Kecanduan Game Online Pada Siswa Kelas XI SMAN 3 Banjarmasin. Jurnal Pelayanan Bimbingan dan Konseling, 3(1), Article 1. http://ppjp.ulm.ac.id/journals/index.php/jpbk/article/view/1592

Handayani, R. (2019). Pengaruh Lingkungan Tempat Tinggal dan Pola Asuh Orangtua Terhadap Motivasi Belajar Siswa Sekolah Dasar. Tunas Bangsa Journal, 6(1), 1526.

Hasgimianti, H., Nirwana, H., \& Daharnis, D. (2017). Perhatian Orangtua dan Motivasi Belajar Siswa yang Berlatar Belakang Melayu dan Jawa. INSIGHT: Jurnal Bimbingan Konseling, 6(2), 130-143. https://doi.org/10.21009/INSIGHT.062.02

Izza, F. K. (2019). Dampak Game Online Terhadap Perilaku Keagamaan Remaja Di Desa Modopuro Mojosari [Undergraduate, UIN Sunan Ampel Surabaya]. In Dampak Game Online Terhadap Perilaku Keagamaan Remaja Di Desa Modopuro Mojosari. http://digilib.uinsby.ac.id/33692/ 
Jafri, Y., Yuni, S. R., \& Sari, Y. P. (2018). Bermain Game Online Dengan Motivasi Belajar Pada Anak Sekolah Dasar. PROSIDING SEMINAR KESEHATAN PERINTIS, 1(1), Article 1. https://jurnal.stikesperintis.ac.id/index.php/PSKP/article/view/62

Jamil, M. M. (2019). Optimalisasi Model ARCS Dalam Pembelajaran Saintifik Untuk Meningkatkan Motivasi Belajar Peserta Didik Pada Peminatan Mata Pelajaran Geografi Di Kelas Matematika Ilmu Alam. IJIS Edu: Indonesian Journal of Integrated Science Education, 1(1), 7-24. https://doi.org/10.29300/ijisedu.v1i1.1401

Mahlianurrahman, M. (2017). Peningkatan Motivasi Belajar Ipa Melalui Implementasi Metode Inquiry Kelas V Sekolah Dasar. Jurnal Ilmiah Sekolah Dasar, 1(4), 252259.

Maryam, S. (2018). Gambaran Tingkat Pendidikan dan Pola Asuh Ibu pada Anak Usia Dini di Gampong Pante Gajah Kecamatan Matang Glumpang Dua Kabupaten Bireuen. Gender Equality: International Journal of Child and Gender Studies, 3(2), 67-76. https://doi.org/10.22373/equality.v3i2.3443

Miles, M. B., Huberman, M. A., \& Saldana, J. (2014). Drawing and verifying conclusions. Qualitative data analysis: A methods sourcebook.

Mumu, M., Majid, A., \& Rohyana, A. (2019). Hubungan Kualitas Kerja Sama Sekolah dan Orang Tua dengan Intensitas Usaha Belajar Siswa di SMP Negeri Kota Tasikmalaya. Jurnal METAEDUKASI, 1(1), Article 1. http://jurnal.unsil.ac.id/index.php/metaedukasi/article/view/980

Nata, A. (2018). Pendidikan Islam Di Era Milenial. Conciencia, 18(1), 10-28. https://doi.org/10.19109/conciencia.v18i1.2436

Pratiwi, N. K. (2017). Pengaruh Tingkat Pendidikan, Perhatian Orang Tua, dan Minat Belajar Siswa Terhadap Prestasi Belajar Bahasa Indonesia Siswa Smk Kesehatan di Kota Tangerang. Pujangga, 1(2), 31.

Roulston, K. (2014). Analysing interviews. The SAGE Handbook of Qualitative Data Analysis, 297-312.

Rumbewas, S. S., Laka, B. M., \& Meokbun, N. (2018). Peran Orang Tua Dalam Miningkatkan Motivasi Belajar Peserta Didik di Sd Negeri Saribi. EduMatSains : Jurnal Pendidikan, Matematika Dan Sains, 2(2), 201-212. https://doi.org/10.33541/edumatsains.v2i2.607

Setiawan, A. A., Johan. (2018). Metodologi penelitian kualitatif. CV Jejak (Jejak Publisher).

Wahidin, W. (2020). Peran Orang Tua Dalam Menumbuhkan Motivasi Belajar Pada Anak Sekolah Dasar. JURNAL PANCAR (Pendidik Anak Cerdas dan Pintar), 3(1), Article 1. https://ejournal.unugha.ac.id/index.php/pancar/article/view/291 
90 | Fidya Hariani, Wiwin Arbaini, \& Dini Palupi Putri

Warsah, I. (2018a). Interkoneksi Pemikiran Al-Ghazāli dan Sigmund Freud Tentang Potensi Manusia. Kontekstualita, 32(01), Article 01. http://ejournal.lp2m.uinjambi.ac.id/ojp/index.php/Kontekstualita/article/view/30

Warsah, I. (2018b). Relevansi Relasi Sosial Terhadap Motivasi Beragama Dalam Mempertahankan Identitas Keislaman di Tengah Masyarakat Multi Agama (Studi Fenomenologi di Desa Suro Bali Kepahiang Bengkulu). Kontekstualita, 32(02), Article 02. https://doi.org/10.30631/kontekstualita.v34i02.42

Warsah, I. (2020). Pendidikan Islam dalam Keluarga: Studi Psikologis dan Sosiologis Masyarakat Multi Agama Desa Suro Bali. Yogyakarta: Tunas Gemilang Press. 